1. Комарова Э. П. Основы обучения иноязычному профессионально ориентированному опосредованному общению в системе вузовского образования / Э. П. Комарова. - Воронеж : Издво ВГТУ, 2000. - 175 с. 2. Пассов Е. И. Основы коммуникативной методики обучения иноязычному общению / Е. И. Пассов. - М. : Русский язык, 1989. - 276 с. 3. Тарнопольский О. Б. Методика обучения английскому языку делового общения: [учеб. пособ.] / О. Б. Тарнопольский, С. П. Кожушко. - К. : Ленвит, 2004. - 191 с. 4. Шубин Э. П. Языковая коммуникация и обучение иностранным языкам / Э. П. Шубин. - M. : Просвещение, $1972 . \quad$ - 350 с. 5. Щукин А. Н. Лингводидактический энциклопедический словарь / А. Н. Щукин. - М. : Астрель: АСТ : Хранитель, 2007. - 746 с. 6. Common European Framework of Reference for Languages: learning, teaching, assessment. - Cambridge: Cambridge University Press, 2001. - 260 p.

УДК 378.14

А. О. Нікора,

кандидат пед. наук, доцент, Миколаївський національний університет імені В. О. Сухомлинського

\title{
СУТНІСТЬ ТА ОСОБЛИВОСТІ МЕТОДИЧНОЇ ПІДГОТОВКИ МАЙБУТНЬОГО ВЧИТЕЛЯ ДО РОБОТИ В УМОВАХ ІННОВАЦІЙНИХ ПРОЦЕСІВ У ШКІЛЬНІЙ СУСПІЛЬСТВОЗНАВЧІЙ ОСВІТІ
}

Нікора А.О. Сутність та особливості методичної підготовки майбутнього вчителя до роботи в умовах інноваційних процесів у шкільній суспільствознавчій освіті.

Стаття присвячена визначенню сутності та розкриттю особливостей методичної підготовки майбутнього вчителя до роботи в умовах інноваційних процесів у шкільній суспільствознавчій освіті.

Ключові слова: методична підготовка вчителя, інноваційний процес, суспільствознавча освіта.

Никора А.А. Сущность и особенности методической подготовки будущего учителя к работе в условиях инновационных процессов в школьном обществоведческом образовании.

Статья посвящена определению сущности и раскрытию особенностей методической подготовки будущего учителя к работе в условиях инновационных процессов в школьном обществоведческом образовании.

Ключевые слова: методическая подготовка учителя, инновационный процесс, обществоведческое образование.

Nikora A. Nature and features methodically preparing future teachers to work in innovative processes in school social science education.

Article is devoted to the definition of the nature and characteristics of the disclosure of methodological training future teachers to work in terms of innovation processes in the school social science education.

Key words: methodical teacher training, innovative process, social science education.

Для ефективного управління складним процесом освіти, що знаходиться в постійній динаміці розвитку, великого значення набуває чинник уміння вчителем передбачати основні тенденції та напрямки наступних змін. В умовах модернізації шкільної суспільствознавчої освіти вчителю не тільки важливо, але й необхідно володіти компетенціями, що дозволяють виявити інноваційну гнучкість.

Питання модернізації суспільствознавчої освіти відображено у працях К. Баханова, А. Булди, О. Пометун, Ф. Турченка, О. Турянської, О. Удода та багатьох інших. Зміни в завданнях, змісті та організації суспільствознавчої галузі досліджувалися науковцями Т. Ладиченко, О. Пометун та ін. Вимоги підготовки якісно нової генерації вчителів, які уміють і готові працювати в умовах швидкоплинних змін відображено у працях О. Глузмана, Л. Нечипоренко, В. Сагарди. Вивченням проблеми підготовки майбутніх учителів (зокрема - методичної) опікуються В. Гриньова, М. Коган, О. Рудницька, А. Старєва та інші. Однак, обгрунтування сутності та особливостей методичної підготовки майбутнього вчителя під кутом його готовності до роботи в умовах інноваційних процесів у 
шкільній суспільствознавчій галузі ще не стало предметом окремого грунтовного наукового дослідження.

Метою статmі $\epsilon$ визначення сутності та розкриття особливостей методичної підготовки майбутнього вчителя до роботи в умовах інноваційних процесів у шкільній суспільствознавчій освіті.

Дослідження методичної підготовки майбутнього вчителя (К. Баханов, А. Булда,

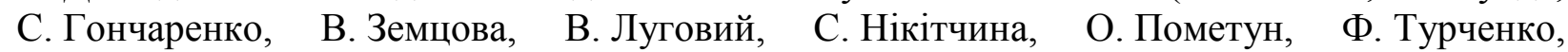
О. Турянська, А. Хуторський, О. Удод) дозволили нам розглядати іiі як багатоелементну структуру, що складається 3 мети i завдань; змісту, принципів його відбору i структурування; методичного забезпечення викладання; системи оцінювання методичної готовності студентів до майбутньої професійної діяльності.

Згідно $з$ позицією М. Скаткіна, методика навчального предмета - педагогічна наука, що досліджує закономірності навчання певного предмета [10, с. 807]. Н. Зеленко методичну підготовку вчителя розуміє як процес формування в майбутніх учителів відповідних знань, умінь та навичок, котрі забезпечать їм можливість проектувати та здійснювати освітній процес [4, с. 35]. Предметно-методична підготовка є складовою професійної підготовки вчителя. В. Луговий визначає іiі як знання предмета і способів його засвоєння учнями [7, с. 91]. На думку В. Земцової, основою предметно-методичної підготовки є сукупність функціональних і структурних компонентів, взаємодія яких породжує інтегративну якість учителя - методичну готовність [5, с. 2].

Дослідницею I. Нікішиною пропонується модель методичного розвитку вчителя, яка передбачає певне соціально-професійне середовище, що забезпечує інтенсивні новоутворення в свідомості майбутнього вчителя та містить такі етапи: пошук своєї позиції, коли педагог усвідомлює, що ефективність його діяльності залежить від продуктивності власних рішень; своєрідний зовнішній і внутрішній професійний діалог критичний аналіз різних варіантів розв'язання конкретного педагогічного завдання; «вибір пріоритету», побудова основ власного авторського варіанту навчання суспільствознавчих дисциплін на основі зіставлення традиційних схем педагогічної діяльності з іiі інноваційними взірцями; ситуація «відмови від стереотипів»-рефлексія власного досвіду, обгрунтування й апробація власної методичної системи [9, с. 91-92].

Для розуміння сутності методичної підготовки майбутнього вчителя до роботи в умовах інноваційних процесів у шкільній суспільствознавчій освіті скористаємось принципом системності, згідно 3 яким методична підготовка розглядається як багатоелементна структура, що складається з мети (прогнозованих результатів навчання) i завдань; змісту, принципів його відбору і структурування; методичного забезпечення викладання (методів, форм, засобів); системи оцінювання методичної готовності студентів-суспільствознавців та з часом конкретизується у професійній діяльності вчителя [6, с. 57-58].

Методична підготовка майбутніх учителів до роботи в умовах інноваційних процесів у шкільній суспільствознавчій освіті $\epsilon$ складовою професійної підготовки вчителясуспільствознавця, що поєднує теоретичний (методики навчання суспільствознавчих дисциплін, спецкурси, спецсемінари 3 методики, самостійну роботу студентів) та практичний (проходження різних видів педагогічних практик) компоненти, а також ураховує сучасні тенденції розвитку шкільної освітньої галузі «Суспільствознавство» та інноваційні тенденції, що відбуваються в системі загальної середньої та вищої освіти України.

У процесі методичної підготовки майбутнього вчителя до роботи в умовах інноваційних процесів у шкільній суспільствознавчій освіті майбутній учитель проходить кілька етапів (зміни позицій): «отримувача» знань про зміст, особливості, традиційні та новітні технології навчання суспільствознавчих дисциплін - «пошукача» (дослідника) характерних форм, методів та засобів навчальної діяльності школяра - «реалізатора» 
методики навчання учнів предметів суспільствознавчої галузі в ході педагогічної практики.

Діяльність викладача також змінюється: від «транслятора» знань і педагогічних технологій через роботу «майстра», що організує спільну діяльність задля формування у студентів психологічних та педагогічних здібностей до роботи в умовах інноваційних змін у шкільній суспільствознавчій освіті, - до позиції «консультанта», «помічника», що спільно зі студентом проектує його майбутню професійну діяльність.

Серед компонентів методичної підготовки майбутнього вчителя до роботи в умовах інноваційних процесів у шкільній суспільствознавчій освіті, ми визначаємо такі: теоретична підготовка студентів, яка здійснюється на лекціях, у ході самостійної роботи, на семінарських заняттях і консультаціях (iї зміст складають інтегровані знання 3 дисциплін «Педагогіка», «Історія педагогіки», «Вікова психологія», «Педагогічна майстерність», методик навчання відповідних предметів тощо); теоретико-практична підготовка студентів - реалізується у ході самостійної роботи, на практичних, семінарських, лабораторних заняттях, навчальних екскурсіях і консультаціях, тренінгах (іі зміст складають методичні знання й навички наукового дослідження, формування предметних компетенцій школярів на уроках і позакласних заходах суспільствознавчого спрямування); практична підготовка студентів, що здійснюється під час педагогічної практики, у ході самостійної роботи, зокрема при виконанні курсової й кваліфікаційної робіт, на методичних семінарах, навчальних екскурсіях і консультаціях (iї зміст складають методичні вміння формування i розвитку учнівських компетенцій на уроках і позакласних заходах та навички їх наукового дослідження).

Система методичної підготовки майбутніх учителів до роботи в умовах інноваційних процесів у шкільній суспільствознавчій освіті передбачає організаційні форми навчання, спрямовані на: 1) набуття студентами знань - лекції, семінарські заняття, навчальні екскурсії, консультації; 2) оволодіння навичками й уміннями - практичні, лабораторні заняття, навчальні конференції, педпрактика; 3) контроль знань, навичок і вмінь модульні контрольні роботи, заліки, іспити, курсова й випускна кваліфікаційна роботи, педагогічна практика. Також виокремлюємо самостійну роботу, спрямовану на формування самоосвітньої компетентності студента, як фундаменту професійного зростання майбутнього вчителя, формування в нього соціально цінних і професійнозначущих якостей [2, с. 74]. Зауважимо, що основними видами занять у вищих навчальних закладах є: лекція, лабораторна робота, практичне, семінарське заняття, консультація. Інші види навчальних занять визначаються в порядку, встановленому вищим навчальним закладом [1].

Аналіз наукової літератури дозволив нам класифікувати методи підготовки майбутнього вчителя за джерелами навчання: комунікативні методи, що охоплюють методи й процедури контакту студента 3 безпосереднім джерелом знань (викладачем методики, шкільним учителем, керівником педагогічної практики, Internet та ін.); текстологічні методи, що передбачають методи набуття знань фахових документів (навчальних планів і програм, методичних листів МОНМС України тощо) i фахової літератури (монографій, підручників, навчальних посібників, методичних рекомендацій, науково-методичних статей).

Комунікативні методи поділяються на пасивні й активні: у перших провідна роль належить викладачеві методики, шкільному вчителю етики (студент лише фіксує зміст лекції, навчальної діяльності вчителя й учнів тощо); в активних методах ініціатива належить студентові, який контактує з викладачем методики, практикуючим учителем. Активні методи поділяються на групові (мозковий штурм, круглий стіл, ділові ігри тощо) та індивідуальні методи (анкетування, інтерв'ювання, вільний діалог, експертні ігри тощо).

Контроль процесу й результату методичної підготовки майбутнього вчителя до роботи в умовах інноваційних процесів у шкільній суспільствознавчій освіті містить: поточний 
контроль, що передбачає процесуальне оцінювання (зокрема самоаналіз, самооцінювання), та підсумковий контроль 3 результативним оцінюванням. Поточний контроль здійснюється в межах таких організаційних форм навчання: семінарських i практичних занять, консультацій, педпрактики, навчальних екскурсій, конференцій, - та включає такі процедури методу процесуального оцінювання: 1) оцінку методичного розвитку студента; 2) процесуальну оцінку його критичного мислення; 3) методичний портфель. Кожна 3 перелічених організаційних форм навчання має власний об'єкт контролю: 1) знання; 2) навички і вміння; 3) самоосвітню компетентність [8, с. 75].

Поточний контроль дозволяє викладачу методики та керівнику педагогічної практики впродовж кожної з організаційних форм навчання отримувати інформацію та надавати іiі студентові передусім про рівень сформованості в нього компонентів методичної готовності до здійснення майбутньої професійної діяльності на конкретному етапі іï формування: методичних знань на семінарських заняттях, навчальних екскурсіях, консультаціях; методичних навичок на практичних заняттях, навчальних конференціях, у ході самостійної роботи; методичних умінь на педпрактиці, а також самоосвітньої компетентності при виконанні курсової й випускної кваліфікаційної робіт і методичного аспекту готовності впродовж усіх організаційних форм навчання. Підсумковий контроль реалізується шляхом таких організаційних форм: модульна контрольна робота, залік, курсовий екзамен, заліковий урок і позакласний захід на педпрактиці, захист курсової й випускної кваліфікаційної робіт.

До необхідних організаційно-технологічних умов якісної підготовки майбутнього вчителя до роботи в умовах інноваційних процесів у шкільній суспільствознавчій освіті ми відносимо: введення у процес професійної підготовки курсів та спецкурсів 3 методик навчання предметів шкільної освітньої галузі «Суспільствознавство»; забезпечення інтегративності системи методичної підготовки майбутнього вчителя; введення до змісту професійно-педагогічних дисциплін тем з питань інноваційного розвитку та інноваційних тенденцій в освіті.

В основу сучасної методичної підготовки майбутнього вчителя, згідно з дослідженнями А. Старєвої, повинні бути покладені системний, компетентністний, особистісно зорієнтований та діяльнісний підходи.

Згідно з системним підходом, учитель, що працює в інноваційному освітньому середовищі, повинен володіти такими компетенціями, як: збір інформації (системно збирати інформацію і використовувати різноманітні джерела при підготовці до уроків); формування концепцій (створювати базисні моделі, формувати концепції, висувати гіпотези та ідеї на основі зібраної інформації; визначати загальну картину процесу; виявляти тенденції, розкривати причиннонаслідкові зв'язки); концептуальна гнучкість (виявляти й оцінювати можливі варіанти при плануванні і прийнятті рішень; одночасно тримати в пам'яті кілька варіантів розв'язків, порівнюючи їх в основному з недоліками).

Основними компонентами готовності майбутнього вчителя суспільствознавчої галузі до роботи в умовах інноваційних тенденцій в освіті у контексті особистісно зорієнтованого підходу є: розуміння оточення (використання «відкритих» і «закритих» питань, констатація і переказ своїми словами почутого для того, щоб зрозуміти ідеї, переконання і почуття співрозмовників; уміння бачити проблеми очима учнів); управління взаємодією (залучення інших, створення груп, члени яких розуміють спільність мети i завдань; уміння планувати і реалізувати спільну науково-дослідницьку і навчальну роботу 3 учнями, колегами; вміння організовувати успішну самостійну діяльність учнів); передача ідей та знань (виклад думки зрозуміло та захоплено, так що співбесідники чи аудиторія легко розуміють сутність повідомлення; ефективне використання різноманітних допоміжних прийомів - технічних засобів, візуальних контактів, символів); прагнення до удосконалення (допомога учням чіткіше уявити власні достоїнства і недоліки, допомога їм у навчанні і подоланні труднощів, що виникають у процесі навчання).

Відповідно до діяльнісного підходу, діяльність $є$ основою, засобом і вирішальною 
умовою розвитку особистості та ії̈ оточення. Такий підхід передбачає передовсім навчання майбутнього вчителя адекватного визначення мети й планування інноваційної діяльності, свідомої iï організації, регулювання, здатності об'єктивного контролю, оцінки й аналізу іï результатів; вміння організовувати власну й учнівську діяльність, реалізовувати нові плани та ідеї.

Особливого значення у процесі методичної підготовки майбутнього вчителя надається компетентнісному підходу, сутність якого полягає у спрямуванні навчального процесу на набуття майбутніми вчителями важливих професійних компетенцій, тобто загальних здатностей особистості, необхідних для виконання педагогічної діяльності. Компетентність грунтується на знаннях, досвіді, цінностях, набутих завдяки навчанню, та $\epsilon$ показником успішності останнього. Залежно від ступеня компетентності вчителя він може володіти такими якостями: прагнення до досконалості, тобто орієнтири на високі внутрішні стандарти, що ставить перед майбутнім учителем високу, але досяжну мету в умовах роботи в інноваційному навчальному середовищі; прагнення виконувати роботу краще і творчо, бажання постійного удосконалення, підвищення ефективності; постійне зіставлення досягнутого результату 3 очікуваними результатами, державними стандартами.

Реалізація сучасних освітніх завдань, що ставить перед майбутнім учителем суспільствознавча галузь, залежить від модернізації його методичної підготовки, професійної майстерності, творчого ставлення до власної праці в контексті запровадження сучасних інновацій, пов'язаних здебільше зі світовими інтеграційними процесами та відповідними змінами, що відбуваються в українській вищій та середній освіті.

Отже, методична готовність майбутнього вчителя до роботи в умовах інноваційних процесів у шкільній суспільствознавчій освіті - це сутнісна характеристика комплексної методичної підготовки, яка $є$ складником професійної підготовки (загальнопедагогічної i предметно-методичної) особистісно, ціннісно-орієнтованого характеру, що грунтується на основі системного, особистісно зорієнтованого, діяльнісного і компетентнісного підходів та характеризується сформованістю у студентів мети, мотивів, відповідних компетенцій навчання учнів суспільствознавчих дисциплін та проведення відповідних уроків під час педагогічних практик i в майбутній професійній діяльності 3 урахуванням новітніх педагогічних тенденцій і методичних розробок.

\section{Література}

1. Болюбаш Я. Я. Організація навчального процесу у вищих закладах освіти : [навч. посіб. для слухачів закладів підв. кваліф. системи вищої освіти] / Я. Я. Болюбаш. - К. : ВВП «КОМПАС», 1997. - 64 с. 2. Вітвицька С. С. Основи педагогіки вищої школи : [підруч. за модульно-рейтинговою системою навчання для студ. магістратури] / С. С. Вітвицька. - Київ : Центр навчальної літератури, 2006. - 384 с. 3. Гура О. І. Педагогіка вищої школи: вступ до спеціальності : [навч. посіб.] / О. І. Гура. - Київ : Центр навчальної літератури, 2005. - 224 с. 4. Зеленко Н. В. Взаимосвязь проектирования и самопроектирования методических компетенций в системе общетехнической и методической подготовки учителя технологии : автореф. дис. на соискание уч. степени д-ра пед. наук: 13.00.02 / Н. В.Зеленко; Армавирский государственный педагогический университет. Астрахань, 2006. - 41 с. 5. Земцова В. И. Система методической подготовки учителя: структура и содержание / В. И. Земцова // Наука и школа. - 2002. - № 3. - С. 2-8. 6. Краевский В. В. Методология педагогического исследования / В. В. Краевский [и др.]. - Самара : Изд-во СГПИ, 1994. - 162 с. 7. Луговий В. І. Педагогічна освіта в Україні : структура, функціонування, тенденції розвитку / В. І. Луговий ; за заг. ред. акад. О. Г. Мороза. - К. : МАУП, 1994. - 196 с. 8. Нагаєв В. М. Методика викладання у вищій школі : [навч. посіб]. - К. : Центр учбової літератури, 2007. - 232 с. 9. Никишина И. В. Подготовка учителей к реализации гуманистической направленности обучения средствами методической работы / И. В. Никишина. - М., 1992. - 160 с. 10. Скаткин М. Н. Дидактика средней школы : [некоторые проблемы современной дидактики] / М. Н. Скаткин. - М. : Просвещение, 1982. - 319 с. 